Article

\title{
Women's Coalitions beyond the Laicism-Islamism Divide in Turkey: Towards an Inclusive Struggle for Gender Equality?
}

\author{
Selin Çağatay \\ Department of Gender Studies, Central European University, 1051 Budapest, Hungary; E-Mail: selincagatay@gmail.com
}

Submitted: 13 April 2018 | Accepted: 28 June 2018 | Published: 22 November 2018

\begin{abstract}
In the 2010s in Turkey, the ruling Justice and Development Party's (AKP) authoritarian-populist turn accompanied the institutionalization of political Islam. As laicism was discredited and labeled as an imposed-from-above principle of Western/Kemalist modernity, the notion of equality ceased to inform the state's gender policies. In response to AKP's attempts to redefine gender relations through the notions of complementarity and fitrat (purpose of creation), women across the political spectrum have mobilized for an understanding of gender equality that transcends the laicism-Islamism divide yet maintains secularity as its constitutive principle. Analyzing three recent attempts of women's coalition-building, this article shows that, first, gender equality activists in the 2010s are renegotiating the border between secularity and piety towards more inclusive understandings of gender equality; and second, that struggles against AKP's gender politics are fragmented due to different configurations of gender equality and secularity that reflect class and ethnic antagonisms in Turkish society. The article thereby argues for the need to move beyond binary approaches to secularism and religion that have so far dominated the scholarly analysis of women's activism in both Turkey and the Nordic context.
\end{abstract}

\section{Keywords}

authoritarian populism; feminism; gender equality struggles; laicism-Islamism divide; piety; secularity; Turkey; women's coalitions

\section{Issue}

This article is part of the issue "Gender Equality and Beyond: At the Crossroads of Neoliberalism, Anti-Gender Movements, 'European' Values, and Normative Reiterations in the Nordic Model”, edited by Lena Martinsson (University of Gothenburg, Sweden), Diana Mulinari (Lund University, Sweden) and Katarina Giritli Nygren (Mid Sweden University, Sweden).

(C) 2018 by the author; licensee Cogitatio (Lisbon, Portugal). This article is licensed under a Creative Commons Attribution 4.0 International License (CC BY).

\section{Introduction}

Recent contributions in gender studies scholarship have widely documented, in Western and non-Western countries alike, the tension between politicized religion and gender equality struggles (e.g., Dhaliwal \& Yuval-Davis, 2014; Jeffreys, 2011; Razavi \& Jenichen, 2010; Tadros, 2015). Simultaneously, feminist movements in many contexts seek strategies to reclaim gender equality while challenging the divisions between secularism and religion (e.g., Cuesta \& Mulinari, 2018; Martinsson, 2016; Moghadam, 2017). In Turkey, the consolidation of political Islam under the rule of the Justice and Development Party (AKP) has recently coupled with all-out discrimination against secular social groups (Eligür, 2010). As I ar- gue in the following, this has inclined gender equality activists (feminist and women's and LGBTQ rights activists of various political persuasions) to organize beyond the laicism-Islamism divide and to build more inclusive struggles for gender equality.

After a decade of EU accession-oriented gender equality reforms in the 2000s, Turkey's gender regime is undergoing significant changes in line with the AKP's authoritarian-populist turn (Akçay, 2018; Esen \& Gümüşçü, 2016; Güneş, 2017). In the institutional framework of politics, gender equality is being replaced by the Islamic notions of fitrat (purpose of creation) that attributes differential natures to men and women, and gender complementarity which designates the family as "the only institution within which women's sexual- 
ity can rightly be expressed and their sanctified role, motherhood, realized" (Özyeğin, 2015, p. 197). In 2017, three significant initiatives of women's coalition-building set out to challenge Turkey's changing gender regime as shaped by AKP's authoritarian populism: the "Don't Mess with My Outfit!" (Kıyafetime Karışma!) campaign, the Equality, Justice, Woman Summit (Eşitlik, Adalet, Kadın Zirvesi), and the "Women Are Strong Together" (Kadınlar Birlikte Güçlü) campaign. All still ongoing, these initiatives have several common features. First, they defend gender equality with secularity as one of its core principles. Second, despite being organized largely by women who identify as feminist, they avoid the use of the controversialized concept of "feminism" in their political framing to form broader alliances. Third, they address "all women", including pious women, with the prospect of mobilizing them against AKP's gender politics. In this article, I analyze these coalition-building initiatives based on ethnographic research conducted online between March 2017 and June 2018, as well as an examination of the media coverage of gender equality activism in the given period. In the case of the third initiative, "Women Are Strong Together", I also integrate the informal exchanges between me and the organizers of the campaign, which took place in March 2018. Analyzing the political dynamics of these initiatives, I show that, first, gender equality activists in the 2010s are renegotiating the border between secularity and piety; second, that struggles against AKP's gender politics are fragmented due to different configurations of gender equality and secularity that reflect class and ethnic antagonisms in Turkish society.

There is a widespread tendency in gender studies scholarship to treat the "laicist" and "Islamist" sections of women's activism as homogenous, binary categories (e.g., Çaha, 2013; Turam, 2012). Contrary to this tendency, some recent studies employ the categories "secular" and "pious" in a non-binary (but still coconstitutive) fashion (e.g., Frank \& Çelik, 2017; Kandiyoti, 2011; Özyeğin, 2015). Building on these studies, I argue that the latter approach allows to better understand the dynamics of coalition-building which reflect the ways in which women articulate gender equality based on their differential political belongings. Following Saba Mahmood, I differentiate between political secularism and secularity, where " $[t]$ he former pertains to the modern state's relationship to, and regulation of, religion, while the latter refers to the set of concepts, norms, sensibilities, and dispositions that characterize secular societies and subjectivities" (Mahmood, 2016, p. 3). In Turkey, political secularism took the form of laicism (laiklik), which entailed that the religion was not removed from, but rather interpreted, overseen, and administered by the Turkish state (Davison, 2003). Since the rise of political Islam in Turkey and globally in the 1980s, laicism has been discursively reconstructed in binary opposition to Islamism. Instead, I suggest an analysis that builds on the concepts of secularity and piety in a mu- tually inclusive manner. As Deniz Kandiyoti has stated, "[t]hose wishing to use religious arguments to achieve [a] more progressive reading of women's rights are de facto members of secular spaces since feminists - of whatever persuasion-have little to gain from a closure of public deliberation" (quoted in Tadros, 2015, p. 664). In the concluding section of the article, I reflect on how such an analysis can also contribute to feminist strategies in the Nordic context.

\section{Laicism-Islamism: A Gendered Divide}

Since the foundation of modern Turkey in 1923, laicism has been one of the key principles that informed Kemalism, the founding ideology of the Republic. More than a simple separation between the state and religion, it functioned as a means to national sovereignty against religious authority and a scientific approach that enabled modern social organization (Çelik, 2006). Kemalist laicism shaped gender relations through a series of reforms in education (in 1924), attire (in 1925), civil rights (in 1926), and language (in 1928). The 1926 Civil Code outlawed polygamy and brought gender equality in the matters of marriage, divorce, child custody and inheritance, thereby strengthening women's position within the family and enabling their public participation in greater numbers. Laicism-related reforms, notwithstanding their ambiguous and not always advantageous results for lower-class women (see Kocabicak, 2018; Makal \& Toksöz, 2012), changed women's social status and involved them as active subjects in nationbuilding processes. Kemalists thought that women were oppressed because of "backward" traditions and "reactionary" interpretations of Islam, and laicism would ensure gender equality between men and women. Yet, in the Kemalist project, laicism was intimately linked to modernism/Westernism and Turkish nationalism. This limited the public inclusion of those women who could not keep up with the modernization/Westernization and Turkification efforts of the new regime. Although Kemalism eliminated religion from the political sphere, it favored a certain interpretation of Islam that was carried out by the Directorate of Religious Affairs (hereafter Diyanet) established in 1924, and maintained the SunniMuslim identity as the desirable moral and behavioral dimension of Turkish citizenship (Atasoy, 2011). Through a strategic use of the modern-traditional binary, the nonTurkish and non-Sunni Muslim populations (e.g., Kurds, Alevis, Arabs) were provided with less access to the Kemalist public sphere, as they were labeled "backward" or "reactionary" subjects in need of modernization. The modern-traditional binary also divided women into the categories "covered" and "uncovered" (see Göle, 1996; Yeğenoğlu, 1998), associating laicism with a lifestyle defined by the adoption of Western attire and mixed-sex socialization as opposed to veiling and gender segregation. Laicism's association with lifestyle rendered gender equality reforms important means to maintain the 
Kemalist imaginary of a classless society. As the moderntraditional binary evolved into the laicism-Islamism divide over the decades, women's attire remained having a central role in discussions around laicism, gender equality, and women's public participation.

After Turkey's transition to a multi-party regime in 1946, right-wing parties in power articulated Islamic beliefs and practices into the official ideology as components of Turkish culture, making it possible for Turkish nationalism to become more widespread than it had previously (Brockett, 2011). Following the 1980 military coup, the 1982 Constitution defined Islam a constituent of the official ideology under the label "Atatürk nationalism". The cultural sphere became subject to strict state surveillance together with the introduction of compulsory religious education and the adoption of the "Turkish-Islamic synthesis" as a dominant educational narrative (Keyman \& Kancı, 2011). Throughout this time, despite the compromises in the implementation of the laicism principle and conservative politicians' increasing emphasis on women's role as mothers and wives (Sancar, 2012), covered women remained excluded from the public sphere and gender equality activists (back then mainly Kemalist and socialist women) did not tackle the problematic relationship between laicism and gender equality. Since the late-1980s, Islamism's gender project has drawn on a modern interpretation of political Islam in which the covered, educated Muslim woman posed a challenge to Western/Kemalist modernity (Çakır, 2000) and to the Kemalist narrative of women's rights. An increasing number of covered women organized against their exclusion from education and civil service. Their active participation in the Islamist civil society and political parties destabilized the proposition that laicism was the precondition for women's public inclusion. At the same time, the laicism-Islamism divide, now a grand narrative into which all other social antagonisms would be articulated (see Kandiyoti, 2012), infiltrated gender equality activism (this time including feminist women), showing itself in the disputes over the headscarf issue (see Çağatay, 2017).

\section{AKP's Authoritarian-Populist Turn and Turkey's Changing Gender Regime}

Coming to power in 2002, the AKP distanced itself from the anti-Western discourse of the previous Islamist parties and supported globalization and Turkey's EU membership while adopting the protection of the family and traditional values in its "Conservative Democracy" program (Coşar \& Özkan-Kerestecioğlu, 2017; Ilkkaracan, 2017). In its first two terms in office (2002-2011), in line with Turkey's EU accession prospect, the party enabled significant improvements in women's rights by incorporating the notion of gender equality in the Constitution (in 2004 and 2010), the Penal Code (in 2004) and the Labor Code (in 2003), and by establishing an Equal Opportunity Commission in the Parliament in 2009 (Aldıkaçtı Mar- shall, 2013; Müftüler-Baç, 2012). In the 2010s, however, the notion of equality ceased to inform the state's gender policies as the AKP discredited laicism by labeling it as an imposed-from-above principle of Western/Kemalist modernity. Starting with the then Prime Minister Tayyip Erdoğan's declaration that he did not believe in gender equality (Cumhuriyet, 2010), fitrat and complementarity gradually became dominant themes in Turkey's gender regime. In 2011, the State Ministry responsible for Women and the Family became the Ministry of Family and Social Policy (Ministry of Labor, Social Services and Family as of June 2018), reflecting the party view on women as primarily mothers, wives, and daughters. In 2015, the Constitutional Court decriminalized religious marriage unaccompanied by civil marriage, abolishing a legal measure that was adopted in 1936 in order to protect the rights that women gained through civil marriage (Kuyucu, 2016). In 2017, the Parliament passed a bill (the so-called Mufti law) that allows muftis (religious civil servants) to perform civil marriages despite the widely held view that this would encourage child marriages and further polarize Turkish society along the laicism-Islamism divide. In the same year, the 2010 prime ministerial circular, issued to increase women's employment and ensure equal opportunities, was revised. In the new draft of the circular the word "equality" was omitted, together with the previously adopted measures of equal pay for equal work, inspection of the establishment of crèches and daycare centers to support women's employment, and inclusion of women's organizations in decision-making processes regarding gender equality at work (Women's Labor and Employment Initiative [KEIG], 2017).

These changes in Turkey's gender regime are not stand-alone developments but crucial to the AKP's authoritarian-populist turn. Since the party came to power, part of its populist strategy has been to deepen the laicism-Islamism divide by building on a discourse of an "omnipotent Kemalist state repressing the weak society" (Alaranta, 2015). The pre-AKP Turkey was narrated as "a land of military tutelage and elitism where secular republican elites oppressed believers with their top-down policies of modernization and betrayed their own Islamic roots with their Westward-looking reforms" (Kandiyoti \& Emanet, 2017, p. 873). Through government-dependent trade unions and civil society (including women's) organizations, the party formulated what was in fact an intra-elite conflict over state power as an antagonism between the people and the elite (Akçay, 2018; Yabancı, 2016). In so doing, the AKP mobilized support for a Muslim nationalism, presenting Turkey as an alternative civilizational center to Europe and nourishing neo-Ottomanist aspirations of becoming a dominant player in the Middle East (Alaranta, 2015; Işıksal \& Göksel, 2018; White, 2013). In the 2010s, challenged by events such as the Gezi-inspired protests of 2013, clashes with the Gülenists (members of a politically powerful Islamist order) within the state, termination of the peace process with the Kurdistan Workers' Party (PKK), and the 
failed coup d'état of 2016, the AKP embarked on increasingly authoritarian ways of ruling to remain in power. The failed coup and the ensuing state of emergencydeclared to purge the Gülenists from both state and private institutions-gave the government a valid excuse to increase the political violence directed towards the social opposition as a whole. In the meantime, AKP's post-coup alliance with the Nationalist Action Party (MHP) further consolidated the nationalist dimension of its authoritarian turn and elevated Erdoğan to the status of the leader of the right-wing electorate (Türkmen \& Küçük, 2016). In all these developments:

Gender norms and specifically women's conduct and propriety play a key role in delineating the boundaries between 'us' (God-fearing, Sunni, AKP supporters), and a 'them' consisting of all political detractors and minorities, cast as potentially treasonous and immoral. (Kandiyoti, 2016, p. 105)

Accompanying AKP's authoritarian-populist turn is the introduction of various mechanisms that privilege (and further impose) a Turkish-Muslim identity. In this, the Diyanet acts as the key institution to realize the party's repeatedly stated mission to raise "pious generations". Diyanet's role in reframing social relations, including gender, is most remarkably observed in changes in the educational system. In the 2010s, religious (imam-hatip) as well as private schools were prioritized over-and at times replaced-secular public schools, reproducing not only the supremacy of the majority sect but also the economic interests of the AKP-favored group of elites (Bayhan, 2017). During this time, the notions of fitrat and complementarity have entered the school curricula through school books deeming marriage with atheist people or people belonging to other religions unacceptable, associating premarital relationships with adultery, and defining woman's obedience to her husband as a religious duty performed in return for the husband's responsibility over the family economy (Cumhuriyet, 2017).

Yet, privileging a Turkish-Muslim identity in itself does not hinder women's public participation. Covered women, already homogenized and utilized by Kemalists and Islamists alike, played an important role in AKP's populist appeal as the party assumed the role of representing Muslim women's rights. Under the AKP rule, the laicism-Islamism divide kept being reproduced over women's bodies but the link between laicism and women's public inclusion further diminished as covered women participated in the public sphere in greater numbers. In the 2000s, drawing on the EU's human rights framework, the party framed the headscarf issue as a matter of individual rights and freedoms. Covered women became visible in the highest ranks of the state, first as wives of the AKP elite, then as bureaucrats and politicians themselves. The rise of an AKPsupported bourgeoisie (Gümüşçü \& Sert, 2009) and the advancement of the Islamist women's movement (Ak- soy, 2015) supported their upward class mobility. Between 2011 and 2016, the ban on the headscarf was removed in public universities, the Parliament, courts, primary education (both for teachers and for girls from age 9), the police department, and various other fields of civil service. Today, nearly 4.5 million women have membership in the women's auxiliaries of AKP (AK Parti Kadın Kolları, 2017). An increasing number of female civil servants are hired in the Diyanet and the Ministry of Labor, Social Services and Family (Ministry of Family and Social Policy until June 2018), institutions responsible for redesigning gender relations according to fitrat and complementarity (see Adak, 2015; Maritato, 2017). AKP's ideal of "strengthening the family institution" does not correspond to women's confinement in the familial sphere; unlike the Kemalist assumption that Islamism and women's public participation were incompatible, the latter proved to be inherent to the AKP's social engineering program.

\section{Repositioning of Gender Equality Activists: Towards an Inclusionary Feminism?}

Alongside the AKP's authoritarian-populist turn and the retrogression in women's rights, several other factors led gender equality activists to reposition themselves vis-à-vis AKP's gender politics and to seek broader alliances to challenge its rule. First, since the beginning of AKP's third term in office (2011-2015), women's organizations that had achieved considerable success in shaping Turkey's gender politics during the EU-oriented reform period were excluded from decision-making processes (Çağatay, 2018; Doyle, 2018). This pushed gender equality activists who previously pursued gender politics in platforms facilitated by Turkey's EU candidacy and the global gender equality regime (Kardam, 2005) into the counter-public sphere, including not only Kemalist, egalitarian, and Kurdish feminists but also Islamist women's rights activists. Second, in this period, "feminism" got discredited, especially by Erdoğan who portrayed feminists as Western agents acting against national interests, "women who did not belong to Turkish-Muslim culture and civilization" (Bianet, 2015). During the post-coup allout attack on the social opposition, feminist journalists, writers, and activists got arrested; academics who supported women's and LGBTQ rights were purged. Kurdish feminists received a disproportionate share of state violence. Politicians (including members of the Parliament) were jailed, women's organizations and news agencies were shut down, municipality-run crisis centers available for women in the Kurdish region closed (Baysal, 2017; Gülbahar, 2017), showing clearly how Islamism and antifeminism intertwined with Turkish nationalism. Third, during the AKP rule, feminism got "side-streamed" (Alvarez, 2014) thanks to feminists' successful awareness raising campaigns as well as their active involvement in various sites of oppositional politics. Opposition parties, particularly the pro-Kurdish People's Democratic Party 
(HDP) and the Kemalist Republican People's Party (CHP), not only participated in the Parliament with feminist MPs but also adopted feminist terminology and analysis in their program (Kabasakal Arat, 2017). Fourth, both the experience of collective action during the Gezi-inspired protests and AKP's populism increasingly dividing people into "us" and "them" encouraged oppositional actors across the political spectrum, including feminists and the pro-Islamist left, to position themselves in an (albeit loosely defined) anti-AKP front. This positioning, together with the side-streaming of feminism, made gender equality a potential pivot point around which demands for equal citizenship could be built.

Finally, yet importantly, the political differentiation between different groups of covered women became visible. The AKP, in the legal processes it initiated to lift the headscarf ban, did not consult with the Islamist women's rights activists, who have been experts on this subject (Aksoy, 2015, p. 161), as these women were involved in gender equality activism. Furthermore, some covered women who were among the AKP's co-founders were later excluded from the party ranks upon criticizing the government's anti-democratic policies. In the postcoup period, Islamist women who were associated with the Gülenists got arrested, lost their jobs, and faced different forms of state violence. Meanwhile, an increasing number of pious women, especially those belonging to the upper classes and younger generations, found a "feminist vein" in themselves through which they "develop[ed] a critique of the masculine understanding and interpretation of gender relations in Islam" (Özyeğin, 2015). Such a feminist vein has also led to political organizing based on a new pious female identity like in the case of the Reçel (jam) Blog or the Muslims Against Violence Towards Women Initiative (see Akyılmaz \& Köksalan, 2016; Özinanır, 2016). As more and more covered women raised their voices against the AKP rule, they became plausible actors for coalition-building against the party's gender politics. Taken together, these factors inclined some gender equality activists to go beyond the laicism-Islamism divide in challenging AKP's gender politics, which made possible the coalition-building initiatives I analyze below.

\subsection{Don't Mess with My Outfit!}

Initiated by the left-feminist "We Will Stop Femicide" Platform (KCDP), the "Don't Mess with My Outfit!" demonstrations took place over the summer of 2017 in Istanbul, Ankara, and Izmir. They were a reaction to the increasing physical and verbal attacks on women who did not cover or dress 'modestly' in public, carried out by men who seemed to have been encouraged by the negative views high rank government representatives and state officials express on the secular lifestyle. That the perpetrators of these attacks were not charged or condemned by government officials strengthened the impression that women who did not adopt a pious lifestyle (thus dress code) were not worthy of state protection. Protestors who gathered at the demonstrations declared that women will not remain silent on the "increasing attacks on women's lifestyle, dress and modern rights" (Bianet, 2017a). Linking these attacks to state policies and the widespread violence against women, they emphasized that the dress and lifestyle-related impositions on women come back to them as violence and murder. Remaining loyal to the KCDP's main agenda, the demonstrations treated violence against women as a universal common ground (see Grewal, 2005) where activists with differential political belongings could meet.

The "Don't Mess with My Outfit!" campaign brought together an array of gender equality activists. Members of the LGBTQ community joined after the Istanbul Pride March was deemed "against public morality" and banned by the authorities (The New Arab, 2017). Kemalist feminists participated in defense of a laic state and against inegalitarian gender politics (Hürriyet, 2017). A young covered woman held a placard that said, "Don't mess with my shorts or my headscarf!", exemplifying how the lifestyle argument appealed to both groups of women. The demonstrations grew into Women's Councils in several cities in Turkey under KCDP's leadership. On March 11, 2018, the Women's Council of Turkey gathered in a meeting in Istanbul, bringing together more than 500 women from 25 different cities. At this meeting, where covered women were a small but visible minority, participants agreed to not allow interventions in women's clothing and discussed how to resist the "outrageous" attempts to regulate women's behavior according to strict gender roles (Deutsche Welle, 2018).

The campaign was a powerful attempt at coalitionbuilding because it drew attention to the instrumentalization of women's attire by governments in the name of political projects of belonging and, as such, it addressed "all women". Yet, the campaign's framing of the relationship between gender equality and secularity primarily as a lifestyle issue is problematic because it limits the differences between women to the cultural/religious sphere, overlooking how women's experience of lifestylebased discrimination differ based on their class position. Since the 2000s, women's increased participation in public life went hand-in-hand with an overall transformation in the relations of production and reproduction through neoliberal policies that deepened the class divisions between women (see Akkan, 2018; KEIG, 2013). Urban, educated, upper-class women who had the financial means to outsource their housework and care work responsibilities could participate in public life on more equal footing with men. But lower-class women's employment in low-paid, flexible, insecure jobs, which were thought to be the continuation of their natural roles as mothers and wives (i.e., based on their fitrat), left them economically dependent on the men in their families or the state (see Alnıaçık, Altan-Olcay, Deniz, \& Gökşen, 2017; Kllıc, 2008). Thus, it is lower-class women who, because of their higher dependence on access to state ser- 
vices, suffer from lifestyle-based discrimination the most. For example, women seeking shelter from male violence might receive aid from the municipality depending on whether they cover (Ilkkaracan, 2017, p. 82), or divorced women might not receive state protection against violence because they "willingly" remain outside the family institution (Özar \& Yakut-Çakar, 2013). Babül's (2015) research on the evaluation of the worthiness of rights seekers show that policy makers' "[p]ortrayals of women and children as innocent, depoliticized victims in need of care and protection...narrows the category of rights bearers by excluding groups who do not conform to the image of the helpless victim" (Babül, 2015, p. 116). In this case, KCDP's homogenization and universalization of women as victims of male violence in relation to lifestyle-based discrimination might not challenge but assist the changing gender regime under the AKP rule, whereas integrating a class perspective would contribute to the de-naturalization of fitrat and complementaritybased arguments.

\subsection{Justice, Equality, Woman Summit}

On November 30 and December 1, 2017, the Equality, Justice, Woman Summit brought together 363 civil society organizations and around 900 women from 48 cities. It was organized by the initiative of Gülseren Onanç from the Kemalist CHP, who gathered an organizing committee of feminist academics and public figures and the logistic support of a CHP-led municipality in Istanbul. The summit was mainly a joint event of egalitarian and Kemalist feminists, but it also hosted a number of left feminist and Islamist women's rights activists. The summit organizers formulated women's struggle for equality and justice as constitutive of a broader oppositional agenda. They drew attention to the loss of impact of women's organizations on gender policy-making in a political atmosphere dominated by violence, militarism, and authoritarianism. All those having democratic demands, regardless of their political belonging, ethnic identity, and sexual orientation, were invited (Kadın Zirvesi, n.d.).

The summit title was strategically chosen to counter the pro-AKP women's agenda to replace "gender equality" with "gender justice". In the 2010s, as women's organizations who previously participated in the EUoriented issue-based platforms were repositioned in the counter-public sphere, AKP-established anti-feminist GONGOs (government-organized non-governmental organizations), such as the Women and Democracy Association (KADEM), took over the role of representing Turkey at transnational feminist processes such as Beijing+20 or the GREVIO (Çağatay, 2018; Doyle, 2018). KADEM, involving both covered and not covered women in its body, advocates for the reorganization of gender relations based on fitrat and complementarity under the brand name "gender justice", arguing that this notion transcends the Western notion of "gender equality" (Hürriyet, 2015). Against this argument, the CHP-supported Equality, Jus- tice, Woman Summit manifests that, without equality, there can be no justice.

Considering the predominant presence of Kemalist feminists as organizers and participants, the lack of any reference to laicism, Kemalism or feminism in the framing of the summit was striking. The CHP leader Kilıçdaroğlu's denunciation of the headscarf's instrumentalization in politics and admission of his party's responsibility in deepening the laicism-Islamism divide (CHP TV, 2017), followed by a panel on "gender equality and egalitarian interpretations of Islam", was a clear invitation for pious women to join the summit. The organizers' intention to form a broad coalition for gender equality was noticeable in the calls they made for organized solidarity among women and the wide range of women's and LGBTQ issues discussed at the summit, including problems in paid employment, access to state services, gender-based violence, participation in politics and decision-making, and the backlash against universal rights (Kadın Zirvesi, n.d.).

Yet, a similarly inclusionary attitude was absent when it came to the topics of nationalism, peace, and the Kurdish conflict. These were addressed neither in the panel topics nor in the final declaration of the summit, an otherwise comprehensive document comprising a set of demands regarding "equal opportunities for citizens of different gender, language, religion, sexual orientation, and political belonging" (Bianet, 2017b). Feminist initiatives that work for the peaceful resolution of the Kurdish conflict, such as the Women's Initiative for Peace, were not invited to participate in the summit. The exclusion of topics related to nationalism and peace from the summit agenda and of pro-Kurdish gender equality activists from the list of invited speakers can be partly explained by the AKP's criminalization of the public support for pro-Kurdish politics as an "act supporting terrorism" and the summit organizers' unwillingness to take the risk of defaming their initiative. But a more accurate explanation seems to be sheer nationalism. Since the 1990s, Kemalists' refusal to coalesce with secular pro-Kurdish actors as equal partners against the rise of Islamist gender politics-despite the importance of Kurdish feminists as allies in articulating gender equality with secularityhas been a constitutive dynamic of the laicism-Islamism divide (Çağatay, 2017). Similarly, the summit organizers' unwillingness to tackle Turkish nationalism and express open support for the peaceful resolution of the Kurdish conflict casts a shadow on their otherwise inclusive coalition for gender equality. Notwithstanding, in May 2018, the summit curator Gülseren Onanç launched the Equality, Justice, Woman Platform that aims to bring together Turkey's gender equality activists in an online platform. Both the participation of the pro-Kurdish HDP representatives in the launch ceremony of the platform (Bianet, 2018) and the focus on issues related to peace and conflict resolution in the platform website (esitlikadaletkadin.org) hint that for Kemalist and egalitarian feminists a more open engagement with the Kurdish con- 
flict and willingness to coalesce with Kurdish feminists might be forthcoming.

\subsection{Women Are Strong Together}

The "Women Are Strong Together" campaign was initiated by a group of feminist and women's rights activists in January 2017. Women involved in the campaign organized simultaneous demonstrations in Istanbul and Ankara in January 2018 against the Diyanet's intrusion into everyday life practices. In the 2010s, Diyanet's weight in shaping gender relations increased as the institution gained more administrative power through its nation-wide Family and Counseling Bureaus and joint projects with the Ministry of Labor, Social Services and Family and the Ministry of Education. Alongside running educational programs on "strengthening the family institution", the Diyanet releases fatwas propagating the notions of fitrat and complementarity, such as labeling feminism as immorality; allowing for men to divorce their wives via email, SMS, or phone call; or approving nine-year-old girls' eligibility for marriage according to Islamic rules (BBC, 2018). Although fatwas are not legally binding, they still have the discursive power to shape social attitudes towards gender. It was the latter fatwa, together with the so-called Mufti law that allowed muftis to perform civil marriages and potentially encouraged child marriages, which urged the "Women Are Strong Together" initiative to react. Organizers of the well-attended demonstrations denounced Diyanet's fatwas that legitimized sexual abuse of young girls and stated that no state institution can express support for sexual crimes. Pointing at the disproportionately big state budget allocated to the Diyanet, they claimed that the taxes collected from women were invested in restricting their lives (Evrensel, 2018).

The demonstrations thus created a common ground for "all women" to unite for equal citizenship rights, without state-imposed restrictions on gender relations. Addressing the state, instead of the AKP government, is an inclusionary strategy of coalition-building because, by pointing to the patriarchal nature of the state as an institution that seeks men's interests, it goes beyond not only the laicism-Islamism binary but also the pro-AKP versus anti-AKP socio-political divide. Since the late-1980s, feminist movements in Turkey have challenged Islamist gender politics from the perspective of patriarchy. In the feminist view, the labeling of the headscarf by Kemalists as "anti-laic", while Islamist men occupied high positions in state institutions, showed how laicism and national identity were constructed by and through women's bodies. Feminists supported covered women's struggle to participate in public life as a demand of equal citizenship but at the same time criticized the conservative, Sunni-Muslim female role model defined by her familial responsibilities. This made it possible for feminists to pursue gender politics without taking sides on the laicismIslamism divide. Similarly, in the demonstrations target- ing the Diyanet, framing gender equality as an institutional alongside a lifestyle issue and demanding the secularity of state organs from the perspective of equal citizenship denounced the privileging of the Turkish-Muslim identity without associating the practice of covering with Islamist politics.

When its agenda is evaluated as a whole, the allencompassing character of the "Women Are Strong Together" campaign comes to light. Gender equality activists involved in the campaign have so far organized a series of events and demonstrations that challenged not only the laicism-Islamism binary but also Turkish nationalism, neoliberalism, and heterosexism. Its flexible organization in the form of issue-based action allows for the participation of feminists of different political persuasions as well as LGBTQ and Islamist women's rights activists, with a changing composition depending on the topic at hand. In terms of women's coalitionbuilding, this flexibility bears potentialities as well as limitations. The strategy to simultaneously address the multiple forms of inequality that disadvantage women without reducing them to AKP's authoritarian populism offers an intersectional political framework for organizations such as the Muslims Against Violence Towards Women Initiative or the Women's Initiative for Peace to articulate their single-issue agendas into a broader struggle for gender equality. As such, the "Women Are Strong Together" campaign comes closest to formulating an inclusive notion of gender equality. Yet, the very flexibility of the campaign hinders the potential to develop its wide range of gender equality demands into a more coherent political program. The antagonistic political belongings of the campaign's participants, such as those of Kemalist and Kurdish feminists, can only be contained, but not transcended, in a loose form of organization that does not provide much space for political deliberation.

\section{Conclusions}

From the early years of the Republic in the 1920s until the end of the 2000s, gender equality and laicism have been constitutive-although instrumentalizedelements of Turkey's official ideology. In the 2010s, AKP's authoritarian-populist turn initiated shifts in the gender regime based on the notions of fitrat and complementarity as part of a Turkish-Muslim social engineering program. This period also saw the disintegration of the relationship between laicism and (covered) women's public participation, political differentiation among covered women, the side-streaming of feminism, and the articulation of gender equality as a potential pivot point around which to build demands for equal citizenship. This conjuncture mobilized gender equality activists to build coalitions that maintained secularity and piety in a mutually inclusive manner.

In this article, I focused on three such initiatives of women's coalition-building and discussed their political dynamics. These initiatives commonly address "all 
women", including pious women, and aim to mobilize them against the AKP's gender politics. Organizers of these initiatives do not refer in their political framing to feminism and laicism but instead to gender equality and secularity, as a tactic to avoid both confrontations over contested topics that might be detrimental to coalition-building and being labeled as marginal, antinational, Western agents. In this framing, they also refrain from publicizing their political affiliations, adopting instead broad titles for their initiatives that can serve as blanket terms. In fact, looking at the constituents of the "Don't Mess with My Outfit!" and "Women Are Strong Together" campaigns and the Justice, Equality, Woman Summit it is clear that various groups organize and/or attend to multiple initiatives of coalition-building simultaneously, making it difficult to draw clear lines of division between gender equality activists' political affiliations. These ongoing initiatives of coalition-building are promising attempts to build solidarity among women beyond the laicism-Islamism divide and to raise demands for equal citizenship. They indicate, as Özyeğin argues, that pious and secular subjects "can no longer perceive one another in terms of rigidly defined anonymous social categories that carry information about each other's moral status and views" (Özyeğin, 2015, p. 224). At the same time, actors who articulate gender equality with secularity are not a uniform 'equality front' but divided from within due to their differential political belongings. Specifically, Turkish nationalism and the Kurdish conflict constitute a major line of division among women's groups; class inequalities are not fully incorporated in gender equality agendas; and LGBTQ issues are only superficially addressed in political framings.

Recent developments in gender equality struggles, some of which I examined here, bring a scholarly need to shift our analytical lens in the study of women's activism away from binary approaches to secularism and religion. Such a shift might be useful in the Nordic context to destabilize the "mythical mantra of gender equality" and to highlight the affinity between the state, nationalism, secularism, and dominant understandings of gender equality (Martinsson, Griffin, \& Giritli Nygren, 2016; see also Liinason, 2018b). There is a striking similarity between the Turkish and Scandinavian models of gender equality in their emphasis on the secular state and identity posed in opposition to traditionalized religion (Berg, Lundahl, \& Martinsson, 2016). Including southern perspectives in discussions within the north, as Kabeer, Stark and Magnus (2008) suggest, can shed light onto the large amount of work to be done with regards to gender equality in Scandinavia by "reversing the gaze". This work includes countering the appropriation of gender equality by racist and right-wing movements as a strategy to portray the migrant Muslim population as a threat to Nordic gender equality (see Mulinari, 2016) as well as identifying the processes of inclusion and exclusion inscribed in gender equality struggles due to antagonisms based on class, ethnic, religious, and national belonging. Address- ing the differences in terms of access to resources and power between not only men and women but also different groups of women would, in turn, enhance Nordic feminist strategies that advocate for a plural notion of feminisms and the constructive co-existence of diverse positions regarding gender equality (Cuesta \& Mulinari, 2018; Liinason, 2018a).

\section{Acknowledgements}

I would like to thank Cemre Baytok, Feride Eralp, Ewa Mączyńska, Katrine Scott, Ece Kocabıçak, the two anonymous reviewers, and the thematic issue editors for their constructive criticism and valuable input on this article.

\section{Conflict of Interests}

The author declares no conflict of interests.

\section{References}

Adak, S. (2015). "Yeni" Türkiye'nin "Yeni” Diyaneti ["New" Diyanet of "new" Turkey]. Birikim, 319, 78-85.

AK Parti Kadın Kolları. (2017). AK Parti Kadın Kolları Bilgilendirme Kitapçığ [AK Party Women's auxiliaries information booklet]. Ankara: AK Parti.

Akçay, Ü. (2018). Neoliberal populism in Turkey and its crisis (Working Paper 100/2018). Berlin: Institute for International Political Economy Berlin.

Akkan, B. (2018). The politics of care in Turkey: Sacred familialism in a changing political context. Social Politics: International Studies in Gender, State \& Society, 25(1), 72-91.

Aksoy, H. A. (2015). Invigorating democracy in Turkey: The agency of organized Islamist women. Politics \& Gender, 11(i), 146-170.

Akyılmaz, Ö., \& Köksalan, M. E. (2016). Türkiye'de Islami Feminizm ve Kadın Kimliğinin Yeniden İnşası: Reçel Blog Örneği [Islamic feminism in Turkey and the reconstruction of female identity: The Reçel Blog example]. eKurgu, 24(2), 126-145.

Alaranta, T. (2015). National and state identity in Turkey: The transformation of the Republic's status in the international system. Lanham: Rowman \& Littlefield.

Aldıkaçtı Marshall, G. (2013). Shaping gender policy in Turkey: Grassroots women activists, the European Union, and the Turkish state. New York, NY: SUNY Press.

Alnıaçık, A., Altan-Olcay, Ö., Deniz, C., \& Gökşen, F. (2017). Gender policy architecture in Turkey: Localizing transnational discourses of women's employment. Social Politics: International Studies in Gender, State \& Society, 24(3), 298-323.

Alvarez, V. (2014). Beyond NGOization? Reflections from Latin America. In V. Bernal \& I. Grewal (Eds.), Theorizing NGOs: States, feminisms, and neoliberalism (pp. 285-300). Durham, NC: Duke University Press.

Atasoy, Y. (2011). Two imaginaries of citizenship in 
Turkey: The Republican and "ethical" models. International Journal of Politics, Culture, and Society, 24(3/4), 105-123.

Babül, E. M. (2015). The paradox of protection: Human rights, the masculinist state, and the moral economy of gratitude in Turkey. American Ethnologist, 42(1), 116-130.

Bayhan, S. (2017). The cultural politics of school relocations: An ethnographic study of an Istanbul neighbourhood school. Critical Studies in Education, 58(3), 356-372.

Baysal, N. (2017). The Kurdish region since the coup attempt. Open Democracy. Retrieved from www. opendemocracy.net/nurcan-baysal/kurdish-regionsince-coup-attempt

BBC. (2018). Son 10 yılda Diyanet'in tartışma yaratan fetva ve açıklamaları [Diyanet's debate-sparking fatwas and announcements in the last 10 years]. BBC Türkçe. Retrieved from www.bbc.com/turkce/ haberler-turkiye-42552621

Berg, L., Lundahl, M., \& Martinsson, L. (2016). Sekularitet: Förstahet genom religion och kön. Kvinder, Køn Og Forskning, 2016(4), 7-19.

Bianet. (2015). Erdoğan: Bu Feministler Filan Var ya [Erdoğan: These feminists, you know...]. Bianet. Retrieved from www.bianet.org/bianet/kadin/162367erdogan-bu-feministler-filan-var-ya

Bianet. (2017a). Kadınlar "Kıyafetime Karışma" Demek İçin Sokaktaydı [Women took the streets to say: "Don't Mess with My Outfit!"]. Bianet. Retrieved from www.bianet.org/bianet/kadin/188707kadinlar-kiyafetime-karisma-demek-icin-sokaktaydi

Bianet. (2017b). Eşitlik, Adalet ve Kadın Zirvesi Sonuç Bildirgesi Açıklandı [Final declaration of Equality, Justice and Woman Summit announced]. Bianet. Retrieved from www.bianet.org/bianet/siyaset/19 2076-esitlik-adalet-ve-kadin-zirvesi-sonuc-bildirgesiaciklandi

Bianet. (2018). Eşitlik, Adalet, Kadın Platformu, Sivil Toplumu Dayanışmaya Çağırıyor [Equality, Justice, Woman Platform calls for solidarity across civil society]. Bianet. Retrieved from www.bianet.org/bianet/ toplumsal-cinsiyet/197635-esitlik-adalet-kadin-plat formu-sivil-toplumu-dayanismaya-cagiriyor

Brockett, G. D. (2011). How happy to call oneself a Turk: Provincial newspapers and the negotiation of a Muslim national identity. Austin, TX: University of Texas Press.

CHP TV. (2017). Eşitlik Adalet Kadın Zirvesi [Equality Justice Woman Summit]. Retrieved from www. youtube.com/watch?v=gJ04axEi598\&t=108s

Coşar, S., \& Özkan-Kerestecioğlu, I. (2017). Feminist politics in contemporary Turkey: Neoliberal attacks, feminist claims to the public. Journal of Women, Politics \& Policy, 38(2), 151-174.

Cuesta, M., \& Mulinari, D. (2018). The bodies of others in Swedish feminism. Gender, Place \& Culture. Advance online publication. https://doi.org/10.1080/
0966369X.2018.1435510

Cumhuriyet. (2010). Buz gibi sözler [Words like ice]. Cumhuriyet. Retrieved from www.cumhuriyet.com. tr/haber/diger/164212/Buz_gibi_sozler.html

Cumhuriyet. (2017). Bakanlığın ders kitapları kadınlardan itaat istiyor [Ministry's course books demand obedience from women]. Cumhuriyet. Retrieved from www.cumhuriyet.com.tr/haber/egitim/816912/Bakan ligin_ders_kitaplari_kadinlardan_itaat_istiyor.html

Çağatay, S. (2017). The politics of gender and the making of Kemalist feminist activism in contemporary Turkey, 1946-2011 (PhD dissertation). Central European University, Budapest.

Çağatay, S. (2018). In, against (and beyond?) the state? Women's rights, global gender equality regime, and feminist counterpublics in 21st-century Turkey. In L. Martinsson \& D. Mulinari (Eds.), Dreaming global change, doing local feminisms (pp. 58-80). New York, NY: Routledge.

Çaha, Ö. (2013). Women and civil society in Turkey: Women's movements in a Muslim society. Farnham: Ashgate.

Çakır, R. (2000). Dindar Kadının Serüveni [Pious women's adventure]. Birikim, 2000(137), 27-35.

Çelik, N. B. (2006). Kemalizm: Hegemonik Bir Söylem [Kemalism: A hegemonic discourse]. In A. Insel (Ed.), Kemalizm (5th ed.). Istanbul: Iletişim Yayınları.

Davison, A. (2003). Turkey, a "secular" state? The challenge of description. The South Atlantic Quarterly, 102(2/3), 333-350.

Deutsche Welle. (2018). Türkiye Kadın Meclisi toplandı [Women's Council of Turkey gathered]. Deutsche Welle. Retrieved from www.dw.com/tr/t\%c3\% BCrkiye-kad\%C4\%B1n-meclisi-topland\%C4\%B1/a-42 928676

Dhaliwal, S., \& Yuval-Davis, N. (Eds.). (2014). Women against fundamentalism. London: Lawrence \& Wishart.

Doyle, J. L. (2018). Government co-option of civil society: Exploring the AKP's role within Turkish women's CSOs. Democratization, 25(3), 445-463.

Eligür, B. (2010). The mobilization of political Islam in Turkey. New York, NY: Cambridge University Press.

Esen, B., \& Gümüşçü, Ş. (2016). Rising competitive authoritarianism in Turkey. Third World Quarterly, 37(9), 1581-1606.

Evrensel. (2018). Kadıköy'de kadınlardan "Diyanet" protestosu ["Diyanet" protest from women in Kadıköy]. Evrensel. Retrieved from www.evrensel.net/haber/ 342677/kadikoyde-kadinlardan-diyanet-protestosu

Frank, A., \& Çelik, A. B. (2017). Beyond Islamic versus secular framing: A critical analysis of reproductive rights debates in Turkey. Journal of Middle East Women's Studies, 13(2), 195-218.

Göle, N. (1996). The forbidden modern: Civilization and veiling. Ann Arbor, MI: University of Michigan Press.

Grewal, I. (2005). Transnational America: Feminisms, diasporas, neoliberalisms. Durham, NC: Duke Univer- 
sity Press.

Gülbahar, H. (2017). 8 Mart 2017: Kadınların Özgürlük Yürüyüşü [8 March 2017: Women's freedom march]. Artı Gerçek. Retrieved from www.artigercek.com/8mart-2017-kadinlarin-ozgurluk-yuruyusu

Gümüşçü, Ş., \& Sert, D. (2009). The power of the devout bourgeoisie: The case of the justice and development party in Turkey. Middle Eastern Studies, 45(6), 953-968.

Güneş, C. (2017). Turkey's new left. New Left Review, 2017(107), 9-30.

Hürriyet. (2015). KADEM Başkan Yardımcısı Sümeyye Erdoğan: Dünya tarihinde kadını ezen uygulamaları en çok Batı'da görürsünüz [KADEM Vice President Sümeyye Erdoğan: The most oppressive practices against women in the world history are seen in the West]. Hürriyet. Retrieved from www.hurriyet.com. $\mathrm{tr} /$ kadem-baskan-yardimcisi-sumeyye-erdogan-dunya -tarihinde-kadini-ezen-uygulamalari-en-cok-batidagorursunuz-28591556

Hürriyet. (2017). Kıyafetime karışma! [Don't mess with my outfit!]. Hürriyet. Retrieved from www.hurriyet. com.tr/yazarlar/ayse-arman/kiyafetime-karisma-405 32040

Ilkkaracan, P. (2017). An analysis of the "conservative democracy" of the justice and development party in Turkey. In Sexual politics in Muslim societies: Studies from Palestine, Turkey, Malaysia and Indonesia (pp. 62-87). Surabaya: GAYa NUSANTARA/CSBR.

Işıksal, H., \& Göksel, O. (2018). Turkey's relations with the Middle East: Political encounters after the Arab spring. New York, NY: Springer.

Jeffreys, S. (2011). Desecularisation and sexual equality. British Journal of Politics \& International Relations, 13(3), 364-382.

Kabasakal Arat, Z. F. (2017). Political parties and women's rights in Turkey. British Journal of Middle Eastern Studies, 44(2), 240-254.

Kabeer, N., Stark, A., \& Magnus, E. (Eds.). (2008). Global perspectives on gender equality: Reversing the gaze. New York, NY: Routledge.

Kadın Zirvesi. (n.d.). Eşitlik, Adalet, Kadın Zirvesi [Equality, Justice, Woman Summit]. Kadın Zirvesi. Retrieved from https://www.kadinzirvesi.org

Kandiyoti, D. (2011). Disentangling religion and politics: Whither gender equality? IDS Bulletin, 42(1), 10-14.

Kandiyoti, D. (2012). The travails of the secular: Puzzle and paradox in Turkey. Economy and Society, 41(4), 513-531.

Kandiyoti, D. (2016). Locating the politics of gender: Patriarchy, neo-liberal governance and violence in Turkey. Research and Policy on Turkey, 1(2), 103-118.

Kandiyoti, D., \& Emanet, Z. (2017). Education as battleground: The capture of minds in Turkey. Globalizations, 14(6), 869-876.

Kardam, N. (2005). Turkey's engagement with global women's human rights. Aldershot: Ashgate.

Keyman, E. F., \& Kancl, T. (2011). A tale of ambiguity: Cit- izenship, nationalism and democracy in Turkey. $\mathrm{Na}$ tions \& Nationalism, 17(2), 318-336.

Kılıç, A. (2008). The gender dimension of social policy reform in Turkey: Towards equal citizenship? Social Policy \& Administration, 42(5), 487-503.

Kocabicak, E. (2018). What excludes women from landownership in Turkey? Implications for feminist strategies. Women's Studies International Forum, 69, 115-125.

Kuyucu, N. (2016). Kadının Adı Yok [Woman has no name]. Praksis, 41(2), 419-442.

Liinason, M. (2018a). Borders and belongings in Nordic feminisms and beyond. Gender, Place \& Culture. Advance online publication. https://doi.org/10.1080/ 0966369X.2018.1461076

Liinason, M. (2018b). Equality struggles: Women's movements, neoliberal markets and state political agendas in Scandinavia. New York, NY: Routledge.

Mahmood, S. (2016). Religious difference in a secular age: A minority report. Princeton, NJ: Princeton University Press.

Makal, A., \& Toksöz, G. (Eds.). (2012). Geçmişten Günümüze Türkiye'de Kadın Emeği [Women's labor in Turkey from past to present]. Ankara: Ankara Üniversitesi Yayınları.

Maritato, C. (2017). "To make mosques a place for women". Female religious engagement within the Turkish presidency of religious affairs. In M. Ersoy \& A. Ozyurek (Eds.), Contemporary Turkey at a glance: II Turkey transformed? Power, history, culture (pp. 39-52). Wiesbaden: Springer VS.

Martinsson, L. (2016). Frictions and figurations: Gender equality norms meet activism. In L. Martinsson, G. Griffin, \& K. Giritli Nygren (Eds.), Challenging the myth of gender equality in Sweden (pp. 163-186). Bristol: Policy Press.

Martinsson, L., Griffin, G., \& Giritli Nygren, K. (Eds.). (2016). Challenging the myth of gender equality in Sweden. Bristol: Policy Press.

Moghadam, V. M. (2017). Women's rights and democratization in Morocco and Tunisia. In J. Cesari \& J. Casanova (Eds.), Islam, gender, and democracy in comparative perspective (pp. 237-265). New York, NY: Oxford University Press.

Müftüler-Baç, M. (2012). Gender equality in Turkey. Brussels: European Parliament. Retrieved from www. europarl.europa.eu/document/activities/cont/20120 4/20120424ATT43808/20120424ATT43808EN.pdf

Mulinari, D. (2016). Gender equality under threat? Exploring the paradoxes of an ethno-nationalist political party. In L. Martinsson, G. Griffin, \& K. Giritli Nygren (Eds.), Challenging the myth of gender equality in Sweden (pp. 137-162). Bristol: Policy Press.

Özar, Ş., \& Yakut-Çakar, B. (2013). Unfolding the invisibility of women without men in the case of Turkey. Women's Studies International Forum, 41(1), 24-34.

Özinanır, S. Y. (2016). Kadın Perspektifli Bir Islami Yorumlama Biçimi Olarak Kadına Şiddete Karşı Müslümanlar 
Inisiyatifi [Muslims Against Violence Towards Women as an interpretation of Islam from women's perspective]. Fe Dergi, 8(1), 118-130.

Özyeğin, G. (2015). New desires, new selves: Sex, love, and piety among Turkish youth. New York, NY: New York University Press.

Razavi, S., \& Jenichen, A. (2010). The unhappy marriage of religion and politics: Problems and pitfalls for gender equality. Third World Quarterly, 31(6), 833-850.

Sancar, S. (2012). Türk Modernleşmesinin Cinsiyeti: Erkekler Devlet, Kadınlar Aile Kurar [The gender of Turkish modernization: Men make states, women make families]. Istanbul: Iletişim Yayınları.

Tadros, M. (2015). From secular reductionism to religious essentialism: Implications for the gender agenda. In R. Baksh \& W. Harcourt (Eds.), The Oxford handbook of transnational feminist movements (pp. 651-667). New York, NY: Oxford University Press.

The New Arab. (2017). Don't mess with my outfit: Turkish women march against violence. The New Arab. Retrieved from www.alaraby.co.uk/english/ news/2017/7/30/dont-mess-with-my-outfit-turkishwomen-protest-violence

Turam, B. (Ed.). (2012). Secular state and religious society: Two forces in play in Turkey. New York, NY: Palgrave Macmillan.

Türkmen, B., \& Küçük, B. (2016). Gezi'den demokrasi nö- betlerine değişen meydan siyaseti [Politics of public square from Gezi to democracy watches]. T24. Retrieved from t24.com.tr/haber/geziden-demokrasinobetlerine-degisen-meydan-siyaseti,354646

White, J. B. (2013). Muslim nationalism and the new Turks. Princeton, NJ: Princeton University Press.

Women's Labor and Employment Initiative. (2013). Türkiye'de Kadın Emeği ve Istihdamı. Sorun Alanları ve Politika Önerileri II [Women's labor and employment in Turkey. Problem areas and policy suggestions II]. Istanbul: KEIG (Kadın Emeği ve Istihdamı Girişimi).

Women's Labor and Employment Initiative. (2017). Kadın Istihdamının Artırılması ve Fırsat Eşitliğinin Sağlanması Genelgesi'ndeki Değişiklikler: Güncelleme Değil, Eşitsizliği Artırma [Changes in the circular on increasing women's employment and achieving equal opportunity: Not an update but advancing inequality]. Istanbul: KEIG (Kadın Emeği ve Istihdamı Girişimi). Retrieved from www.keig.org/?p=3559

Yabancı, B. (2016). Populism as the problem child of democracy: The AKP's enduring appeal and the use of meso-level actors. Southeast European and Black Sea Studies, 16(4), 591-617.

Yeğenoğlu, M. (1998). Colonial fantasies: Towards a feminist reading of Orientalism. Cambridge: Cambridge University Press.

\section{About the Author}

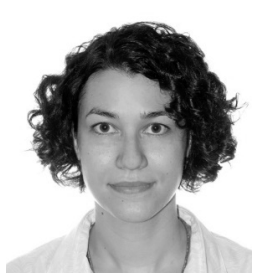

Selin Çağatay holds a PhD degree in Comparative Gender Studies from Central European University (CEU) in Budapest, Hungary. Currently she is a Visiting Lecturer at the Department of Gender Studies at CEU and the Department of European Studies at Eötvös Loránd University, Budapest, Hungary. Her research interests include women's and feminist activism, gender regimes, intersectionality studies, NGOs, secularism, Turkish political history, and women's paid and unpaid labor. 